\title{
Characterization of a novel antimicrobial peptide from buffalo casein hydrolysate based on live bacteria adsorption
}

\author{
Qiong Zhao, Yanan Shi, Xuefeng Wang, and Aixiang Huang*(i) \\ College of Food Science and Technology, Yunnan Agricultural University, Kunming 650201, Yunnan, China
}

\begin{abstract}
This study aims to isolate the antimicrobial peptide (AMP) from buffalo casein hydrolyzed by Dregea sinensis Hemsl. protease. The AMP was isolated from hydrolysate by live bacteria adsorption, then analyzed using reversed-phase high-performance liquid chromatography, and the fraction with highest antimicrobial activity was identified by liquid chromatography-tandem MS. Further, we characterized the peptide in terms of its peptide sequence, structure, and antimicrobial activity. The results identified the AA sequence of the peptide as YLGYLEQLLRLK, which corresponds to residues 106 to 117 of bovine $\alpha_{S 1}$-casein, and we named it BCp12. BCp12 displays $\alpha$-helical structure, with high hydrophobic moments and net positive charge. BCp12 can inhibit the growth of indicator bacteria, with minimum inhibitory concentration values ranging from 0.8 to $1.6 \mathrm{mg} / \mathrm{mL}$, and can induce low toxicity in mammalian cells. Antimicrobial activity of the $\mathrm{BCp} 12$ peptide remained stable under different salt concentrations but was sensitive to trypsin and high temperatures $\left(121^{\circ} \mathrm{C}\right.$ and above). The results support further research in the application of our newly generated AMP as an antimicrobial agent in the food industry and in food processing facilities.
\end{abstract}

Key words: buffalo casein, antimicrobial peptide, adsorption, safety, $\alpha$-helical structure

\section{INTRODUCTION}

Antimicrobial resistance is a serious public health threat that results from the selective pressure exerted by antibiotic use and abuse (Farhana et al., 2019). To reduce antimicrobial resistance, alternatives to antibiotics are urgently necessary, particularly in the food industry (Ma et al., 2019). In recent years, researchers have searched for natural sources of antimicrobial agents, including peptides, oligosaccharides, and plant

Received March 22, 2020.

Accepted July 18, 2020.

*Corresponding author: aixianghuang@126.com extracts (Gao et al., 2019). Antimicrobial peptides (AMP) have antiseptic activity and do not develop resistance, so can be used as an alternative to antibiotics (Ciumac et al., 2019).

In higher eukaryotes, AMP are components of the innate immune system to fight pathogens such as viruses, bacteria, fungi, and even cancer cells (Pichu et al., 2009; Peters et al., 2010). By 2017, more than 10,585 AMP have been found and used (Porto et al., 2017). Although synthetic AMP have been generated, natural AMP occur in both prokaryotes and eukaryotes and can be extracted from food proteins by enzymatic hydrolysis (Zasloff, 2002; Pellegrini, 2003). Antimicrobial peptides penetrate the outer membranes of gram-negative bacteria and the cell walls of gram-positive bacteria, creating holes that lead to leakage of intracellular contents (López-Expósito and Recio, 2008). Most AMP have helical, amphipathic, and hydrophobic structures, with positive charge (Bougherra et al., 2017). In general, it is suggested that peptide drugs exhibit lower toxicity and higher specificity and are more easily synthesized and modified than nonpeptide drugs; thus they have great potential for control of bacterial contamination (Lombardi et al., 2019).

Milk proteins are currently the main source of a range of biologically active components that exhibit various physiological activities (Meisel, 1998; Haque et al., 2008). Milk caseins are an important source of AMP, and most AMP are derived from food proteins in milk (Florisa et al., 2003; Sibel Akalın, 2014). Some peptides from milk caseins demonstrating antimicrobial activity, reported in the literature, are released by enzymatic hydrolysis of plant sources such as protease extracted from the latex of Jacaratia corumbensis (Arruda et al., 2012) and papain (Abdel-Hamid et al., 2016). New protease-mediated hydrolysis of casein may release new AMP (Arruda et al., 2012). The extract from the stem of Dregea sinensis Hemsl. has long been used in making Rubing cheese in Dali, Yunnan Province, China. A cysteine protease with good performance in conversion of milk to curd was identified from Dregea sinensis Hemsl. The protease has a molecular weight of $23.803 \mathrm{kDa}$; its optimal temperature of milk clotting was $80^{\circ} \mathrm{C}$, and it 
was stable in the $\mathrm{pH}$ range 6.0 to 9.0. It has been used to make cheese and release bioactive peptides from goat milk. (Zhang et al., 2015; Wang et al., 2017; Zhao et al., 2018). Buffalo milk produced in Tengchong, Yunnan Province, China, a regional milk, has been found to be different from that of Holstein cows (Zhang et al., 2012). However, until now no information has been published about the AMP from Dregea sinensis Hemsl. protease hydrolyzed from buffalo casein (BC).

Herein we describe the purification and identification of an AMP formed by the hydrolysis of casein from buffalo milk by a self-purified Dregea sinensis Hemsl. protease using live bacteria adsorption. Moreover, to better apply the purified peptide in the field of food preservation, its antimicrobial activity, structure, and safety were also studied.

\section{MATERIALS AND METHODS}

\section{Materials}

Fresh buffalo milk was purchased in Tengchong, Yunnan Province, China. Acetonitrile of gradient grade for liquid chromatography was purchased from Merck KGaA (Darmstadt, Germany). All other chemicals and reagents were of analytical grade and commercially available.

\section{Microbial Strains and Culture}

Escherichia coli CICC 10003, Staphylococcus aureus CICC 10384, Listeria monocytogenes CMCC 54004, Salmonella typhimurium CICC 21484 were purchased from the China Center of Industrial Culture Collection (Beijing). Listeria monocytogenes CMCC 54004 was obtained from the College of Food Science and Technology, Yunnan Agricultural University (Kunming, Yunnan Province, China). Bacterial strains were conserved at $-80^{\circ} \mathrm{C}$ in glycerol containing nutrient broth and were subcultured twice in Luria-Bertani broth medium under agitation (100 rpm) at $37^{\circ} \mathrm{C}$ for $24 \mathrm{~h}$ before use. The initial concentration of cells was adjusted to $10^{6}$ $\mathrm{cfu} / \mathrm{mL}$ by dilution in PBS ( $\mathrm{pH}$ 7.4, containing $137 \mathrm{mM}$ $\mathrm{NaCl}, 2.7 \mathrm{~m} M \mathrm{KCl}, 10.1 \mathrm{~m} M \mathrm{Na}_{2} \mathrm{HPO}_{4}$, and $1.8 \mathrm{mM}$ $\mathrm{KH}_{2} \mathrm{PO}_{4}$, without calcium and magnesium) for subsequent experiments.

Human skin epithelial cells $(\mathrm{HaCaT})$ were provided by the Moringa Institute of Yunnan Agricultural University. Cells were stored with $90 \%$ fetal bovine serum and $10 \%$ dimethyl sulfoxide at $-80^{\circ} \mathrm{C}$ and cultured in RPMI 1640 medium containing 10\% heat-inactivated fetal bovine serum (Hyclone Laboratories, Logan, UT) and $1 \%$ penicillin streptomycin antibiotic mixture (Gibco, Waltham, MA). All cell lines were cultured at $37^{\circ} \mathrm{C}$ in a humidified atmosphere at $5 \% \mathrm{CO}_{2}$ and $95 \%$ air.

\section{Enzyme Extraction}

Dregea sinensis Hemsl. stems (60 g) were cut into small pieces ( 5 to $10 \mathrm{~cm}$ ) and mixed with $600 \mathrm{~mL}$ of 50 $\mathrm{m} M$ phosphate buffer ( $\mathrm{pH} 6.5$ ) containing $2.5 \% \mathrm{NaCl}$ for $12 \mathrm{~h}$ at $4^{\circ} \mathrm{C}$. The protease was partially purified by ammonium sulfate precipitation (25-35\%). This protease was lyophilized after dialysis. The purity of protease was determined by SDS-PAGE that showed a band. Its activity was $314.378 \mathrm{U} / \mathrm{mg}$.

\section{Preparation of Casein from Buffalo Milk}

Skim milk was prepared from whole buffalo milk by centrifugation at $4,000 \times g$ for $20 \mathrm{~min}$ at $4^{\circ} \mathrm{C}$. Casein from skim buffalo milk was prepared based on a previously described method (Mulvihill, 1992), with slight modification. Skim milk was acidified to 4.6 with citric acid $(0.2 M)$ under continuous stirring at room temperature. After curd degradation for $20 \mathrm{~min}$, the mixture was centrifuged at $4,000 \times g$ for $20 \mathrm{~min}$ at $4^{\circ} \mathrm{C}$. The precipitated casein was washed 3 times with distilled water. The final precipitates were adjusted to $\mathrm{pH} 7.0$ with $\mathrm{NaOH}(1 M)$ and then heated at $80^{\circ} \mathrm{C}$ for $30 \mathrm{~min}$ to inactivate the plasmin, dialyzed against distilled water, and freeze-dried.

\section{Preparation of BC Hydrolysates}

Buffalo casein was dissolved in Tris- $\mathrm{HCl}$ buffer (50 $\mathrm{m} M, \mathrm{pH} 8.5$ ) at a concentration of $20 \mathrm{mg} / \mathrm{mL}$. Dregea sinensis Hemsl. protease was pre-incubated for $10 \mathrm{~min}$ and mixed with $\mathrm{BC}$ at an enzyme-to-substrate ratio of $1: 45$ (wt/wt). After $4.5 \mathrm{~h}$ of hydrolysis at $54^{\circ} \mathrm{C}$, the reaction was stopped by boiling for $15 \mathrm{~min}$ and cooling to room temperature in an ice bath. The BC hydrolysate was centrifuged at $10,000 \times g$ for $20 \mathrm{~min}$ at $4^{\circ} \mathrm{C}$ (TLG20M, Changsha Maijiasen Instrument Equipment Co. Ltd., Changsha, China) to remove insoluble material, and the supernatant was adjusted to $\mathrm{pH} 7.0$ with $\mathrm{NaOH}(1 \mathrm{M})$, microfiltered $(0.22 \mu \mathrm{m}$, Millipore, Billerica, MA), and stored at $-20^{\circ} \mathrm{C}$ for further analysis.

\section{Fractionation of BC Hydrolysates by Ultrafiltration}

The hydrolysate was fractionated with ultrafiltration membranes with molecular mass cutoff sizes of 10 and 1 kDa. A stirred UF device (UFSC40001, Millipore) with membranes of 76-mm diameter (NMWL, PES, Millipore) was used. The permeate and retentate of each stage of filtration were collected and lyophilized. Frac- 
tionation stages of $\mathrm{BC}$ hydrolysates by ultrafiltration (BCHU) were marked as follows: BCHU1 $(>10 \mathrm{kDa})$, BCHU2 $(<10 \mathrm{kDa})$, BCHU3 $(>1 \mathrm{kDa},<10 \mathrm{kDa})$, and BCHU4 $(<1 \mathrm{kDa})$. The different fractionations were dissolved in distilled water and filtered using a $0.22-\mu \mathrm{m}$ filter. The inhibition rates of E. coli and Staph. aureus were determined, to select the fractionations with highest inhibition rates.

\section{Separation of AMP by Live E. coli Adsorption (BCHU4-LE)}

The AMP were screened using the method of Tang et al. (2009), with slight modification. Fifteen $\mathrm{mL}$ of cultured E. coli were washed 3 times with $0.9 \% \mathrm{NaCl}$, followed by centrifugation at $10,000 \times g$ for $10 \mathrm{~min}$ to remove culture medium and metabolites. Ten milliliters of BCHU4 $(20 \mathrm{mg} / \mathrm{mL})$ were incubated with live E. coli at $37^{\circ} \mathrm{C}$ for $4 \mathrm{~h}$, and the mixed liquid was centrifuged at $10,000 \times g$ for $10 \mathrm{~min}$. The supernatant of BCHU4 after affinity adsorption by live E. coli (BCHU4-LE), without AMP, was microfiltered $(0.22 \mu \mathrm{m})$ for reversedphase (RP)-HPLC analysis. The RP-HPLC fingerprint chromatograms of BCHU4 and BCHU4-LE were compared to find the different peaks. The fraction with strongest antimicrobial activity was identified via liquid chromatography-tandem MS (LC-MS/MS).

\section{RP-HPLC Fingerprint Chromatogram Analysis of BCHU4 and BCHU4-LE}

The fingerprint chromatograms of BCHU4 and BCHU4-LE were determined via RP-HPLC (Agilent 1200, Agilent Technologies, Santa Clara, CA) using a C18 column (Agilent XDB-C18; $250 \times 4.6 \mathrm{~mm}, 5 \mu \mathrm{m}$ ). The 2 solvent reservoirs contained the following eluents: (A) $0.05 \%$ (vol/vol) trifluoroacetic acid (TFA) and (B) $100 \%$ acetonitrile. Linear gradients were conducted from $5 \%$ to $80 \%$ solvent B over solvent $\mathrm{A}$ in $30 \mathrm{~min}$ with a flow rate of $0.6 \mathrm{~mL} / \mathrm{min}$. Elution was monitored by ultraviolet absorbance at $215 \mathrm{~nm}$. Peaks showing reduced peak area were collected, concentrated, and dialyzed against distilled water (with a molecular weight cutoff of $100 \mathrm{Da}$ ). Their antimicrobial activity was measured to select the most active fraction.

\section{Peptide Identification via LC-MS/MS}

The fraction obtained by RP-HPLC with the highest antimicrobial activity was processed for peptide identification. The LC-MS/MS analysis was performed according to Otte et al. (2007) and Shazly et al. (2017). The sample was dissolved in Nano-HPLC Buffer A and separated by Nano-HPLC (EASY-nLC1200; Thermo
Fisher Scientific, Waltham, MA) liquid phase system. Mobile phase A consisted of $0.1 \%$ formic acid in water; phase B consisted of $0.1 \%$ formic acid in acetonitrile. The trap column (RP-C18, $100 \mathrm{~m} \times 20 \mathrm{~mm}$, Thermo Fisher) was balanced with $100 \%$ liquid A. Samples were loaded by automatic sampler and adsorbed to the trap column and then separated by analysis column (RPC18, $75 \mathrm{~m} \times 150 \mathrm{~mm}$, Thermo Fisher) at a flow rate of $300 \mathrm{~nL} / \mathrm{min}$. Cleaning between the samples was performed with a blank solvent gradient for $30 \mathrm{~min}$. The samples were separated by capillary HPLC and then analyzed by Q-Exactive MS (Thermo Fisher), which was calibrated with standard correction fluid before use. Analysis time was $60 \mathrm{~min}$, positive ion detection method, spray voltage of $2.5 \mathrm{kV}$. Ion transport capillary temperature was $320^{\circ} \mathrm{C}$, with mother ion scanning in the range of $300-1,600 \mathrm{~m} / \mathrm{z}$. Mass spectrometry scanning was performed in the information-dependent analysis (IDA) mode, collecting the 10-piece map (MS2 scan) after each full scan. High-energy collision dissociation (HCD) fracture mode was used, with normalized collision energy (NCE) of 28, dynamic elimination time $30 \mathrm{~s}$. The first mass spectrum $\left(\mathrm{MS}^{1}\right)$ has a resolution of 70,000 at $200 \mathrm{~m} / z$, and the second mass spectrum $\left(\mathrm{MS}^{2}\right)$ has a resolution of 35,000 at $200 \mathrm{~m} / z$. Profile mode was used to collect $\mathrm{MS}^{1}$, and $\mathrm{MS}^{2}$ was collected in centroid mode, to reduce the size of data files. Mass spectra of peptides were exported and compared with the UniProt Bos taurus database (https://www.uniprot .org/proteomes/UP000009136), using Discoverer 2.3 software (Thermo Fisher). Fragment mass tolerance was $\pm 10 \mathrm{ppm}$ and $0.02 \mathrm{Da}$ with phosphorylation as dynamic modification; otherwise, default settings were used.

\section{Peptide Synthesis}

The identified peptides were chemically synthesized by Guoping Pharmaceutical (Anhui, China) based on AA sequences. The purity of the synthetic peptide was above $98 \%$ by HPLC analysis, and its molecular mass was confirmed by MS. Antimicrobial activities of the synthetic peptides will also be determined.

\section{Character Determination of AMP}

The hydrophobicity and helical hydrophobic moment of AMP were determined in the AVPdb Database (http://crdd.osdd.net/servers/avpdb/), and the AMP Database (APD3: Antimicrobial Peptide Calculator and Predictor, http://aps.unmc.edu/AP/prediction/ prediction_main.php). Helical wheel projections were generated with the wheel.pl script via web server (http: //www.bioinformatics.nl/cgi-bin/emboss/pepwheel). 
To investigate the secondary structure under different environments, $0.2 \mathrm{mg} / \mathrm{mL}$ peptide solutions were

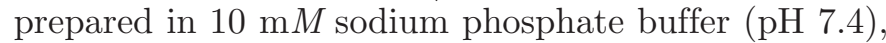
$30 \mathrm{~m} M$ SDS (Sigma-Aldrich, St. Louis, MO), or $50 \%$ 2,2,2-trifluoroethanol (TFE; Sigma-Aldrich). Circular dichroism (CD) assays were then performed using a JASCO 810 spectropolarimeter (Jasco, Tokyo, Japan). The CD spectra were recorded from $195 \mathrm{~nm}$ to $250 \mathrm{~nm}$ using a quartz cell with a 1.0-mm path length.

\section{Antimicrobial Activity Assay}

Agar Disk Diffusion Assay. The antimicrobial activity of the purified peptide against 4 bacteria strains was tested by the agar disk diffusion method of Fang et al. (2019). Briefly, $150 \mu \mathrm{L}$ of bacteria $\left(\times 10^{6} \mathrm{cfu} /\right.$ $\mathrm{mL}$ ) were uniformly plated on a Luria-Bertani medium plate. After $20 \mathrm{~min}$, sterile paper disks $(6 \mathrm{~mm})$ were placed on the seeded agar plates. We added $8 \mu \mathrm{L}$ of synthetic peptide (dissolved in sterile water, $\mathrm{pH}$ 6.8) to the sterile paper disks and incubated in a closed humidified container for $3 \mathrm{~h}$ at $4^{\circ} \mathrm{C}$, for the sample to diffuse into the gel. Tetracycline was used as a positive control for antimicrobial activity, and sterile water served as a negative control. Finally, the plates were incubated at $37^{\circ} \mathrm{C}$ for $12 \mathrm{~h}$, and the diameter of the bacterial growth inhibition zone was measured.

Minimum Inhibitory Concentration. The MIC is defined as the lowest concentration of an AMP that inhibits the growth of a microorganism following incubation at $37^{\circ} \mathrm{C}$ for $12 \mathrm{~h}$, as measured at an absorbance of $630 \mathrm{~nm}$ (Multiskan MK3, Thermo Fisher). The MIC of the purified peptide was measured in sterile 96-well microplates (costar 3599, Corning Inc., Ewloe, UK) using a modified version of the method of Kobbi et al. (2015). Each well included $190 \mu \mathrm{L}$ of fresh LuriaBertani medium, $50 \mu \mathrm{L}$ of peptide solution, and $10 \mu \mathrm{L}$ of bacteria $\left(\times 10^{6} \mathrm{cfu} / \mathrm{mL}\right)$. Sterile water was used as control. The inhibition rate was calculated according to the following equation:

$$
\text { Inhibition rate }(\%)=\left[\left(\mathrm{A}_{0}-\mathrm{A}_{1}\right) / \mathrm{A}_{0}\right] \times 100,
$$

where $A_{0}$ and $A_{1}$ represent the optical density (OD) values at $630 \mathrm{~nm}$ of the control and the sample, respectively.

\section{Stability Assays}

The stability of the purified peptide was determined as previously described (Tang et al., 2015). The antimicrobial activity of the purified peptide under different conditions (heating, salt, and trypsin) was evaluated by measuring $\mathrm{OD}_{630}$ of Staph. aureus as an indicator bacteria, following the same protocol as for MIC assays. The effect of salt on the recovered antimicrobial activity of the purified peptide by treating Staph. aureus with the purified peptide, dissolved in sterile water at a final concentration $0.80 \mathrm{mg} / \mathrm{mL}$ (according to the $\mathrm{MIC}$ ), in the presence of $\mathrm{NaCl}, \mathrm{KCl}, \mathrm{MgCl}_{2}$, or $\mathrm{CaCl}_{2}$ (initial concentrations of $5 \%, 10 \%$, and $15 \%$, wt/vol). To determine the effect of temperature on the recovered antimicrobial activity of the purified peptide against Staph. aureus, the AMP was incubated at different temperatures between $70^{\circ} \mathrm{C}$ and $121^{\circ} \mathrm{C}$ for $30 \mathrm{~min}$. To test the effect of trypsin on the antimicrobial activity of the purified peptide against Staph. aureus, the purified peptide was incubated with $0.2 \mathrm{mg} / \mathrm{mL}$ of trypsin at $37^{\circ} \mathrm{C}$ for $0 \mathrm{~h}, 1 \mathrm{~h}$, and $2 \mathrm{~h}$. Sterile water was used as blank, and nontreated peptide served as control. After treatment, the recovered activity of the purified peptide was evaluated as previously described. Recovered activities are calculated as

$$
(\mathrm{U})=\left(\mathrm{A}_{0}-\mathrm{A}_{1}\right) /\left(\mathrm{A}_{0}-\mathrm{A}_{2}\right) \times 100,
$$

where $\mathrm{U}$ is recovered activity and $\mathrm{A}_{0}, \mathrm{~A}_{1}$, and $\mathrm{A}_{2}$ are $\mathrm{OD}_{630}$ of the blank, the sample, and the control, respectively.

\section{Hemolysis and Cytotoxicity Assay}

The hemolytic activity of the purified peptide was determined as previously described (Ji et al., 2014), with slight modification. Fresh rabbit red blood cells were washed and diluted to $4 \%$ with PBS ( $\mathrm{pH} 7.4$ ). The red blood cell suspension was added to 96-well plates $(100 \mu \mathrm{L} /$ well $)$, mixed with the same volume of serially diluted peptide $(4 \mathrm{mg} / \mathrm{mL}, 2 \mathrm{mg} / \mathrm{mL}, 1 \mathrm{mg} /$ $\mathrm{mL}, 0.5 \mathrm{mg} / \mathrm{mL}$ ), and incubated at $37^{\circ} \mathrm{C}$ for $1 \mathrm{~h}$ with shaking $(200 \mathrm{rpm})$. The plate was centrifuged, and the supernatant was transferred to a new 96 -well plate. The absorbance at $414 \mathrm{~nm}$ was measured with a Multiskan MK3 reader (Thermo Fisher), with $0.1 \%$ Triton X-100 and PBS used as positive and negative controls, respectively. The hemolysis rate was calculated as follows (Han et al., 2016):

$$
\text { Hemolysis }(\%)=\left[\left(\mathrm{A}-\mathrm{A}_{0}\right) /\left(\mathrm{A}_{1}-\mathrm{A}_{0}\right)\right] \times 100,
$$

where $\mathrm{A}$ is $\mathrm{OD}_{414} \mathrm{~nm}$ in the peptide solution, $\mathrm{A}_{0}$ is $\mathrm{OD}_{414}$ in PBS, and $\mathrm{A}_{1}$ is $\mathrm{OD}_{414}$ in $0.1 \%$ Triton $\mathrm{X}-100$.

A3-(4,5-dimethylthiazol-2-yl)-2,5diphenyltetrazolium bromide (MTT) assay, a technique to measure cell survival, was carried out according to the method of 
Table 1. Growth inhibition rates (\%) of Escherichia coli and Staphylococcus aureus by buffalo casein (BC) and by $\mathrm{BC}$ hydrolysate by ultrafiltration (BCHU)-derived peptides with different molecular weights (initial peptide concentration: $80 \mathrm{mg} / \mathrm{mL}$ ); data presented as mean $\pm \mathrm{SD}^{1}$

\begin{tabular}{lrc}
\hline Fraction & $\begin{array}{c}\text { Escherichia coli } \\
\text { CICC } 10003\end{array}$ & $\begin{array}{c}\text { Staphylococcus aureus } \\
\text { CICC 10384 }\end{array}$ \\
\hline BC & $-14.317 \pm 2.259^{\mathrm{a}}$ & $-17.523 \pm 4.170^{\mathrm{A}}$ \\
BCHU1 $(>10 \mathrm{kDa})$ & $51.304 \pm 2.523^{\mathrm{b}}$ & $17.413 \pm 3.856^{\mathrm{B}}$ \\
BCHU2 $(<10 \mathrm{kDa})$ & $80.983 \pm 6.287^{\mathrm{d}}$ & $34.190 \pm 1.378^{\mathrm{C}}$ \\
BCHU3 $(>1 \mathrm{kDa},<10 \mathrm{kDa})$ & $71.101 \pm 1.570^{\mathrm{c}}$ & $33.748 \pm 2.951^{\mathrm{C}}$ \\
BCHU4 $(<1 \mathrm{kDa})$ & $83.192 \pm 0.707^{\mathrm{d}}$ & $46.213 \pm 7.591^{\mathrm{D}}$ \\
${ }^{\mathrm{a}-\mathrm{d}, \mathrm{A}-\mathrm{D} \text { Means within a row with different superscripts differ }(P<0.05) .}$ \\
${ }^{1}$ CICC $=$ China Center of Industrial Culture Collection (Beijing).
\end{tabular}

Mosmann (1983). Briefly, human skin epithelial cells $(\mathrm{HaCaT})$ cultures $\left(3 \times 10^{5}\right.$ cells $\left./ \mathrm{mL}\right)$ were prepared in 96-well plates, and $200 \mathrm{~mL}$ of serial dilutions $(0.8$ to $1.6 \mathrm{mg} / \mathrm{mL}$ ) of either purified peptide or $20 \mathrm{mg} / \mathrm{mL}$ SDS (positive control) were added. Fresh Eagle's minimum essential medium (E-MEM) was used as negative control. Plates were incubated for $24 \mathrm{~h}$ at $37^{\circ} \mathrm{C}$ in a humidified $5 \% \mathrm{CO}_{2}$ atmosphere. After, the medium was replaced by $50 \mu \mathrm{L}$ of MTT solution $(1 \mathrm{mg} / \mathrm{mL}$; USB Corporation, Cleveland, $\mathrm{OH}$ ) prepared in E-MEM medium, and the plates were incubated for $4 \mathrm{~h}$ at $37^{\circ} \mathrm{C}$. The MTT solution was removed without disturbing the cells, and $100 \mathrm{~mL}$ of dimethyl sulfoxide was added to each well to dissolve formazan crystals. After gently shaking the plates for $10 \mathrm{~min}$, the absorbance was read at $540 \mathrm{~nm}$ (Multiskan MK3, Thermo Fisher). The percentage of viable cells was calculated as $A_{T} / A_{C}$, where $\mathrm{A}_{\mathrm{T}}$ and $\mathrm{A}_{\mathrm{C}}$ are the absorbances of treated and control cells, respectively.

\section{Statistical Analysis}

All experiments were performed in triplicate. Data are presented as mean \pm standard deviation. Statistical significance $(P<0.05$; Duncan's test $)$ was determined using SPSS version 22.0 software (IBM Corp., Armonk, NY). Graphs were made using GraphPad Prism 8.0.1 (GraphPad Software Inc., La Jolla, CA) and Adobe Illustrator CS6 (Adobe Inc., San Jose, CA).

\section{RESULTS AND DISCUSSION}

\section{Inhibition Rates of BC Hydrolysates}

The BC hydrolysates were ultrafiltered and incubated with E. coli and Staph. aureus, to determine their growth inhibitory capacity. The bacterial growth inhibition rates of ultrafiltration components (BCHU) with different molecular weights are shown in Table 1. Compared with BCHU, BC did not show antimicrobial activity against the indicator bacteria. Conversely,
BCHU exhibited antimicrobial activity to varying degrees. Among the different fractions, BCHU4 $(<1 \mathrm{kDa})$ showed significantly higher inhibitory effect against $E$. coli and Staph. aureus than the others. Therefore, we chose this fraction (BCHU4) for further AMP isolation by live $E$. coli affinity adsorption. Similar results were reported previously for camel casein and Apostichopus japonicas protein hydrolysates, from which AMP with molecular weight $<1 \mathrm{kDa}$ were isolated during ultrafiltration (Meng et al., 2016; Almi-Sebbane et al., 2018). Previous research has revealed that peptides with low molecular weight could exhibit effective antimicrobial activity (Al Saiqali et al., 2018).

\section{Selective Separation of AMP by Live E. coli Adsorption}

In addition to the active peptides, the total hydrolysate contains a large number of peptides without antimicrobial activity (Bougherra et al., 2017). The method of live E. coli affinity adsorption was used to selectively absorb the AMP contained in the hydrolysate, which avoided cumbersome separation methods (e.g., ion exchange, gel filtration, liquid chromatography). In this study, the major steps for separation of AMP from BC hydrolysate are shown in Figure 1. Seven steps form the core of this approach: (1) obtaining the component (BCHU4) with antimicrobial activity; (2) culturing and washing E. coli; (3) affinity adsorption; (4) collecting the supernatant (BCHU4-LE) by centrifugation; (5) analyzing the differential peaks of BCHU4 and BCHU4-LE via RP-HPLC fingerprint; (6) collecting the fraction with the strongest antimicrobial activity; and (7) identifying the fraction via LC-MS/MS.

\section{Purification and Identification of AMP}

The RP-HPLC fingerprints of BCHU4 and BCHU4LE are shown in Figure 2A, which shows 3 peaks (F1, F2, and F3) with decreasing areas after incubation with live E. coli. The adsorption of live E. coli to 
BCHU4 suggested that these fractions might contain AMP, which could be interacting with the live E. coli. Three fractions were manually collected, and their antimicrobial activities were tested. We found that F3 was the most effective against Staph. aureus. The purified F3 fraction was subjected to LC-MS/MS to determine its molecular weight and AA sequence. Four peptides (YLGYLEQLLRLK, TKVIPYVRYL, AYFYPEL, and PFPIIV) were identified from F3 and chemically synthesized (Supplemental Table S1, https://doi.org/10 $.3168 /$ jds.2020-18577). We measured the antimicrobial activity of these 4 peptides respectively and found that the activity of peptide YLGYLEQLLRLK was significantly higher than the others (Table 2). Thus, peptide YLGYLEQLLRLK was selected as the target AMP in this study. Peptide YLGYLEQLLRLK corresponded to the AA residues 106 to 117 of bovine $\alpha_{\mathrm{S} 1}$-casein. We found no AMP matching it in the NCBI (https:// www.ncbi.nlm.nih.gov/protein/?term=) or APD databases, suggesting the peptide is novel; we thus named it $\mathrm{BCp} 12$.

The purity of synthesized BCp12 is shown in Figure $2 \mathrm{~B}$, illustrating a single peak (purity above $98 \%$ ). The BCp12 from BCHU4 $(<1 \mathrm{kDa})$ had a molecular weight 1,508.82 Da. Because UF membrane is not an absolute filter membrane, its molecular weight cutoff efficiency will have a range (about 800-1000 Da). However, membrane retention efficiency may also be affected by UF pressure. As Almi-Sebbane et al. (2018) reported, tandem MS analysis of the most active fraction, that with the lowest molecular mass $(<1 \mathrm{kDa})$, showed a molecular mass between 1 and $2 \mathrm{kDa}$, which suggested that UF separation does not rely upon a strict molecular mass threshold. That is, the separation between peptides crossing the UF membrane or not is also influenced by peptide conformation, as well as by potential interactions between peptides leading to the formation complexes with higher molecular mass than individual peptides.

Previous reports have also shown that some peptides probably derived from $\alpha_{\mathrm{S}_{1}}$-casein exhibit bactericidal activity in vitro against various pathogenic bacteria, such as Staph. aureus (Gobbetti et al., 2004; LópezExpósito et al., 2006). Our results indicate that live E. coli adsorption can efficiently separate AMP from complex casein hydrolysate, in a simpler way than classic purification methods.

\section{Structure Prediction and Characterization of BCp12}

Helical wheel modeling was used to predict the hydrophobic and hydrophilic regions in $\mathrm{BCp} 12$, having determined $66 \%$ hydrophobic ratio and 2 positive charges for BCp12. The peptide was shown to be a hydrophobic and cationic AMP (Figure 3A). To determine the secondary structure of peptides in membrane-mimicking environments, CD spectra were obtained from peptides dissolved at a final concentration of $0.2 \mathrm{mg} / \mathrm{mL}$ in the following solutions: $10 \mathrm{~m} M$ sodium phosphate buffer, $\mathrm{pH} 7.2$, which mimics the aqueous environment; $30 \mathrm{mM}$

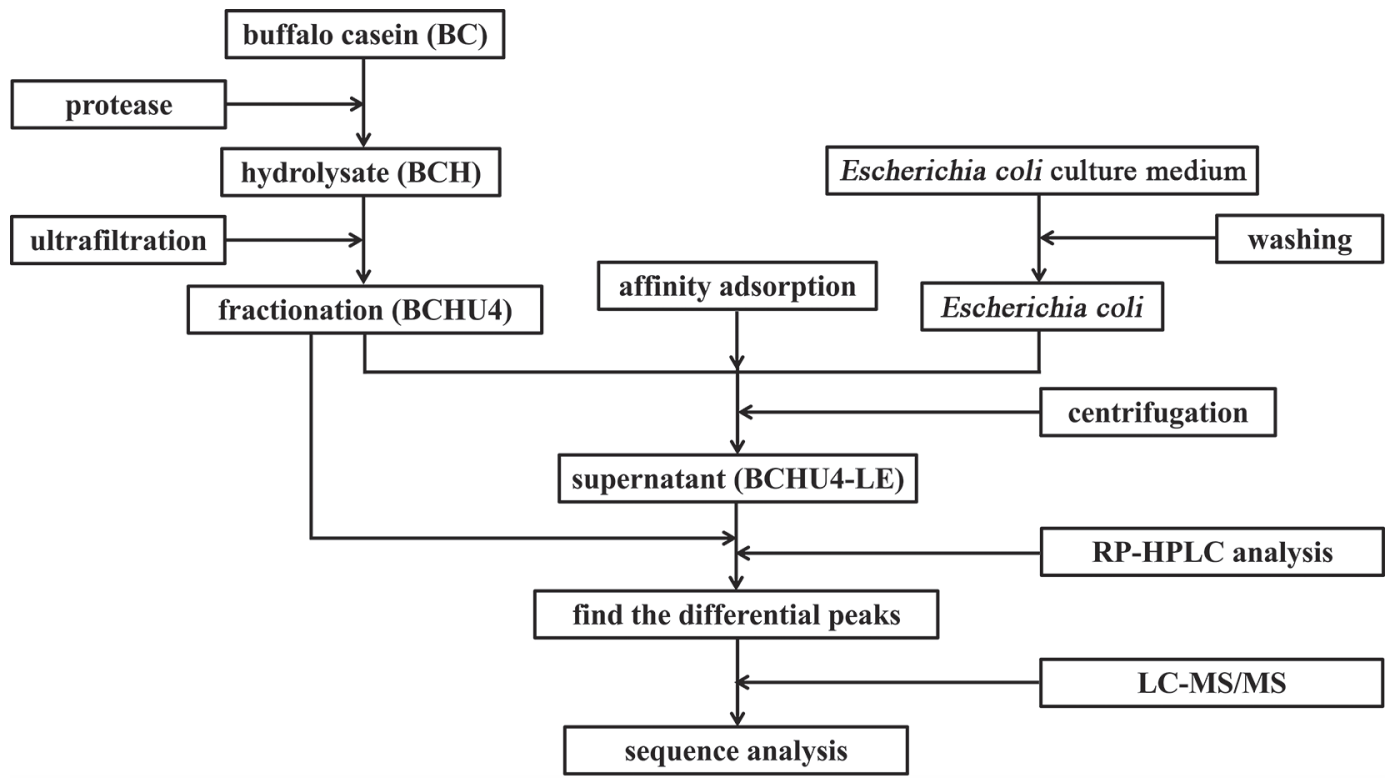

Figure 1. Flowchart of purification of antimicrobial peptides from buffalo casein hydrolysate by live Escherichia coli affinity adsorption. RP-HPLC = reversed-phase HPLC; LC-MS/MS = liquid chromatography-tandem MS. BCH = buffalo casein hydrolysate; BCHU4 = buffalo casein hydrolysate ultrafiltration (molecular weight $<1 \mathrm{kDa}$ ); BCHU4-LE = supernatant of BCHU4 after affinity adsorption by live $E$. coli. 

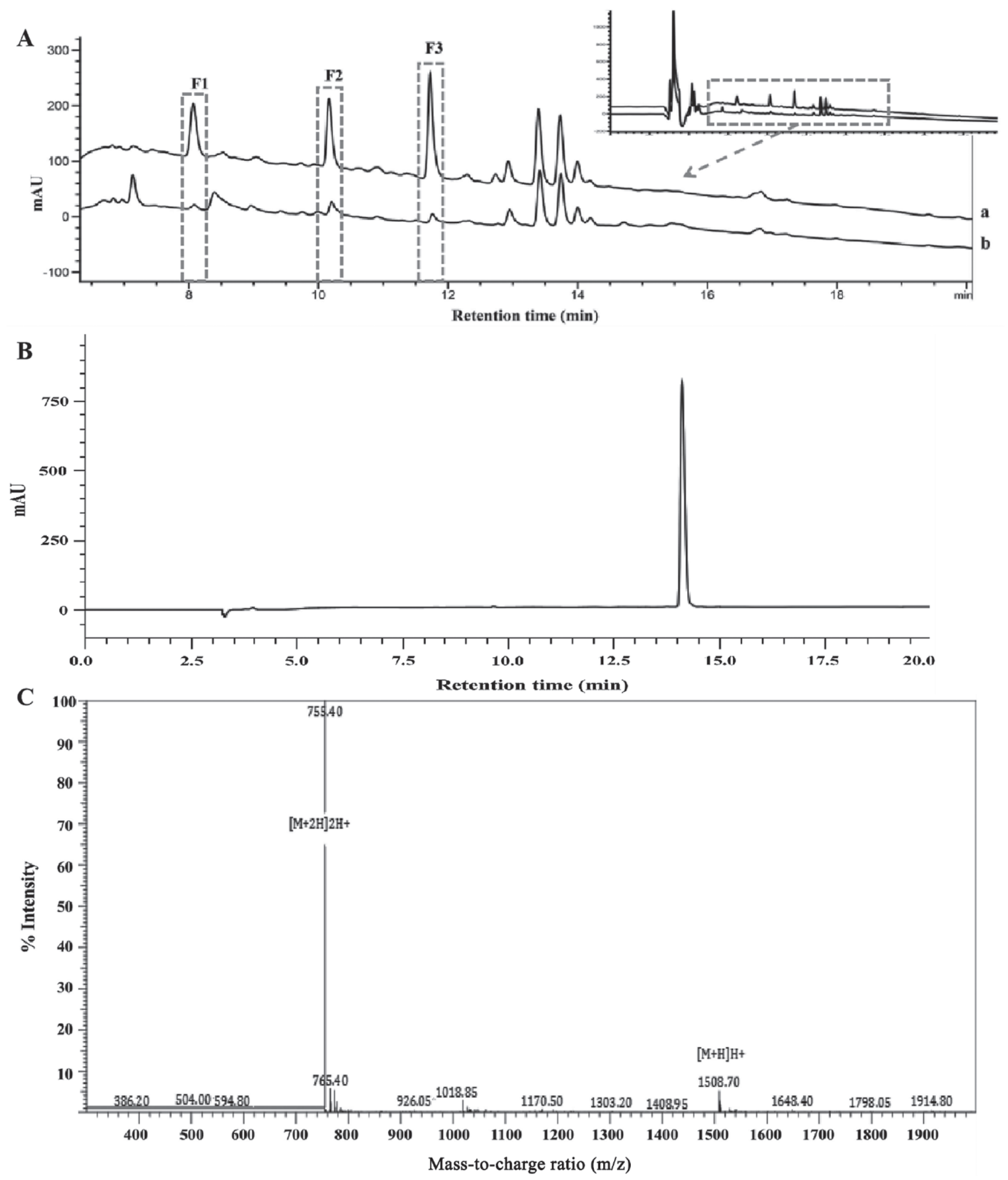

Figure 2. Purification and identification of antimicrobial peptides. (A) Liquid phase diagram: a = buffalo casein hydrolysate by ultrafiltration (BCHU4, before adsorption), $\mathrm{b}=\mathrm{BCHU} 4-\mathrm{LE}$ (the supernatant of BCHU4 after affinity adsorption by live Escherichia coli). F1, F2, and F3 = difference peaks 1, 2, and 3. (B) Reversed-phase-HPLC (Agilent 1200; Agilent Technologies, Santa Clara, CA) profile of novel peptide BCp12. Column type: Agilent XDB-C18; $250 \times 4.6 \mathrm{~mm}, 5 \mu \mathrm{m}$. The profile was eluted at a flow rate of $1.0 \mathrm{~mL} / \mathrm{min}$; inject volume $10 \mu \mathrm{L}$. (C) MS spectrum (LC-2010A, Shimadzu Inertsil, Tokyo, Japan; column type: Shimadzu Inertsil ODS-SP, $4.6 \times 250 \mathrm{~mm} \times 5 \mu \mathrm{m}$, Shimadzu Inertsil) of BCp12. 

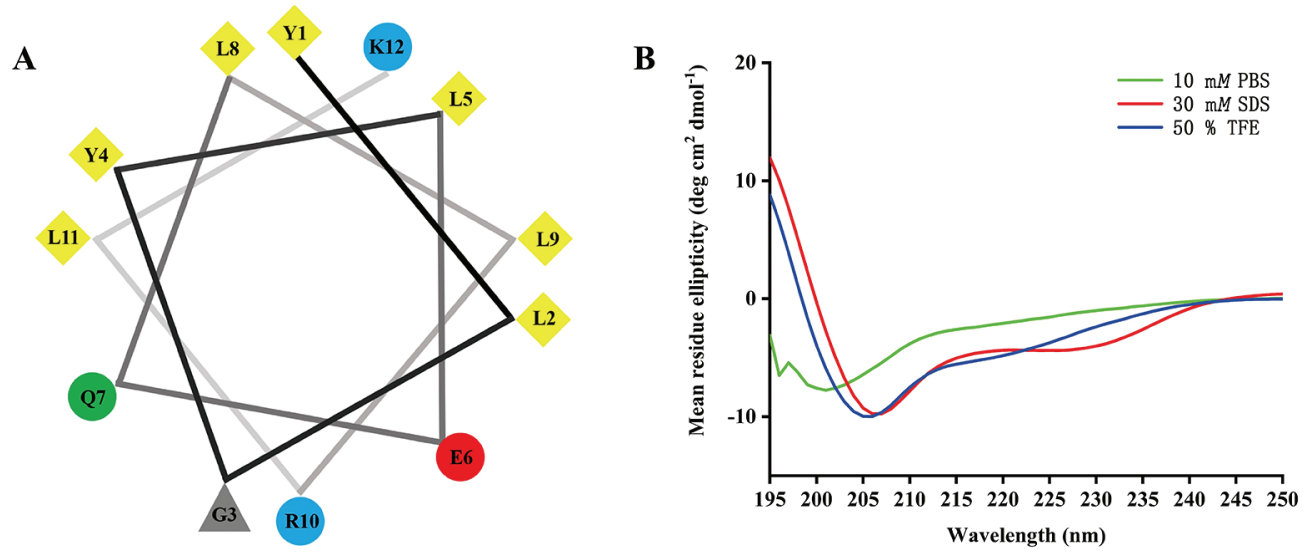

Figure 3. Structural characteristics of novel peptide BCp12. (A) Helical wheel projection of BCp12. The hydrophobic residues are represented in yellow, hydrophilic residues in circles, negatively charged residues in red, positively charged residues in blue, and particular polar residue in gray. (B) Circular dichroism spectra of BCp12 in PBS, in SDS, and in trifluoroethanol (TFE).

SDS, which mimics the negatively charged prokaryotic membrane environment; and 50\% TFE, which mimics the hydrophobic environment of microbial membranes (Kim et al., 2018). The CD analysis (Figure 3B) showed that BCp12 in $30 \mathrm{mM}$ SDS and 50\% TFE solution had negative ellipticities at about $208 \mathrm{~nm}$ and $222 \mathrm{~nm}$, respectively, indicating that the secondary structures of BCp12 were mainly of $\alpha$-helical conformation, suggesting that the peptides adopted an $\alpha$-helical conformation in membrane-mimicking environments.

\section{Antimicrobial Activity of BCp12}

Antimicrobial activity of $\mathrm{BCp} 12$ was determined against the gram-positive bacteria Staph. aureus CICC 10384 and L. monocytogenes CMCC 54004, as well as the gram-negative bacteria E. coli CICC 10003 and Salmonella typhimurium CICC 21484. As shown in Table 3, BCp12 was active against both gram-positive and gram-negative bacteria, with MIC values ranging from 0.8 to $1.6 \mathrm{mg} / \mathrm{mL}$. In addition, the MIC of BCp12 against gram-positive bacteria was lower, indicating that the gram-positive bacteria used in this experi-

Table 2. Growth inhibition rates of Staphylococcus aureus by F3 (difference peak 3 in Figure $2 \mathrm{~A}$ ) and by 4 chemically synthesized peptides at the same concentration; data presented as mean $\pm \mathrm{SD}$

\begin{tabular}{lc}
\hline Sequence & Inhibition rate $(\%)$ \\
\hline F3 & $87.284 \pm 1.670^{\mathrm{c}}$ \\
YLGYLEQLLRLK & $89.944 \pm 1.210^{\mathrm{d}}$ \\
TKVIPYVRYL & $53.198 \pm 2.664^{\mathrm{b}}$ \\
AYFYPEL & $25.840 \pm 1.304^{\mathrm{a}}$ \\
PFPIIV & $52.412 \pm 1.590^{\mathrm{b}}$ \\
\hline
\end{tabular}

\footnotetext{
${ }^{\mathrm{a}-\mathrm{d}}$ Means within a row with different superscripts differ $(P<0.05)$.
}

ment were more susceptible to BCp12 than the gramnegative bacteria were. The diversity of bacterial cell structure may lead to differences in the antimicrobial activity of $\mathrm{BCp} 12$. Compared with previous reports, the BCp12 peptide showed similar MIC values against gram-negative bacteria (Hayes et al., 2006).

An agar disk diffusion test was performed to evaluate the antimicrobial activity of BCp12 (Figure 4A). The values of the diameter of the inhibition zone showed that BCp12 was able to inhibit Staph. aureus growth. The diameter of the BCp12 inhibition zone was about $11.500 \mathrm{~mm}$. Tetracycline, a broad-spectrum antibiotic, was used as positive control $(15.333 \pm 0.577 \mathrm{~mm})$.

The growth of Staph. aureus under different BCp12 concentrations $(0,0.5$, or $1.0 \mathrm{MIC})$ was studied to correlate the observed bacterial density at $630 \mathrm{~nm}$ with the antimicrobial efficacy of the BCp12. As shown in Figure 4B, in the absence of BCp12 (the control), Staph. aureus showed a normal growth curve, with lag, exponential, stationary, and declining growth phases within $24 \mathrm{~h}$. Upon incubation with $0.5 \mathrm{MIC}$, we observed that BCp12 barely affected the growth of Staph. aureus, but it did postpone the late exponential phase of the growth curve. When bacteria were treated with BCp12 at 1.0 MIC, we observed that the growth of Staph. aureus was significantly inhibited within $24 \mathrm{~h}$.

\section{BCp12 Sensitivity to Trypsin, Temperature, and Salt Concentrations}

The trypsin sensitivity of BCp12 is shown in Figure $5 \mathrm{~A}$. We detected no significant change in the antimicrobial activity of BCp12 treated for $0 \mathrm{~h}$. But after 1 and 2 $\mathrm{h}$ of trypsin treatment, activity of BCp12 was reduced significantly $(P<0.05)$ compared with the control. 
Table 3. Minimum inhibitory concentration (MIC) of novel peptide BCp12, an antimicrobial peptide from buffalo casein hydrolyzed by Dregea sinensis Hemsl. protease

\begin{tabular}{llc}
\hline Item & Bacterial strain & $\begin{array}{c}\text { MIC of BCp12 } \\
(\mathrm{mg} / \mathrm{mL})\end{array}$ \\
\hline Gram-positive bacteria & Staphylococcus aureus CICC 10384 & 0.8 \\
& Listeria monocytogenes CMCC 54004 & 1.0 \\
Gram-negative bacteria & Escherichia coli CICC 10003 & 1.6 \\
& Salmonella typhimurium CICC 21484 & 1.4 \\
\hline
\end{tabular}

Only $74.679 \%$ activity of BCp12 remained after $1 \mathrm{~h}$ of treatment, and $68.109 \%$ activity of $\mathrm{BCp} 12$ remained after $2 \mathrm{~h}$ of treatment. To maintain the antimicrobial activity of BCp12, we suggested that trypsin should be avoided in the actual application environment of BCp12. If BCp12 is used in vivo, some techniques may help protect it from trypsin damage. Most AMP are sensitive to in vivo enzymes such as trypsin; a potential solution is microencapsulation, through which peptide drugs are encapsulated, preventing degradation, and allowing the drug to release in a sustained and controlled manner (Zhang, 2011).

As depicted in Figure 5B, a temperature increase from $70^{\circ} \mathrm{C}$ to $115^{\circ} \mathrm{C}$ yielded no significant effect $(P>$ 0.05 ) of the antimicrobial activity of $\mathrm{BCp} 12$ against Staph. aureus; BCp12 retained more than $95 \%$ of its activity after being heated from $70^{\circ} \mathrm{C}$ to $115^{\circ} \mathrm{C}$ for $30 \mathrm{~min}$. Our results indicate that $\mathrm{BCp} 12$ is stable at temperatures below $115^{\circ} \mathrm{C}$, suggesting its potential application as a food preservative in thermal processing. But when incubated at $121^{\circ} \mathrm{C}$ for $30 \mathrm{~min}, \mathrm{BCp} 12$ activity was significantly decreased $(P<0.05)$ to $40 \%$ of its original activity. Not all AMP can retain their original antimicrobial activity after high-temperature treatment. Similar results were obtained for lysozymederived peptides, produced by limited protease hydro- lysis of hen egg lysozyme, which lost about $57 \%$ of their original antimicrobial activity after treatment at $121^{\circ} \mathrm{C}$ for 15 min (Abdou et al., 2007).

Salt environments have a negative effect on AMP (Kim et al., 2018). When AMP interact with bacteria, they first bind to the bacterial cell membrane through electrostatic attraction (Brogden, 2005). The ionic strength in the environment affects the surface charge of the AMP, thus affecting the binding of the AMP to bacterial cells. Therefore, we studied the salt stability of $\mathrm{BCp} 12$. Figure $5 \mathrm{C}$ shows recovered antimicrobial activities of Bcp12 treated with different salts. The antimicrobial effect did not change significantly $(P>$ $0.05)$ in the presence of a concentration of $5 \% \mathrm{NaCl}$, $5 \% \mathrm{CaCl}_{2}$, and $10 \% \mathrm{CaCl}_{2}$. However, antimicrobial effectiveness was significantly reduced $(P<0.001)$ in the presence of concentrations of $15 \% \mathrm{NaCl}, 10 \% \mathrm{KCl}$, $15 \% \mathrm{KCl}, 15 \% \mathrm{MgCl}_{2}$, and $15 \% \mathrm{CaCl}_{2}$. The addition of high-concentration ions weakened the electrostatic interaction between AMP and bacteria and reduced AMP binding (Bellamy et al., 1993).

\section{Hemolytic and Cytotoxic Activities of BCp12}

Although BCp12 is sensitive to trypsin, as described above, it is still expected to be used in vivo. Therefore,
A

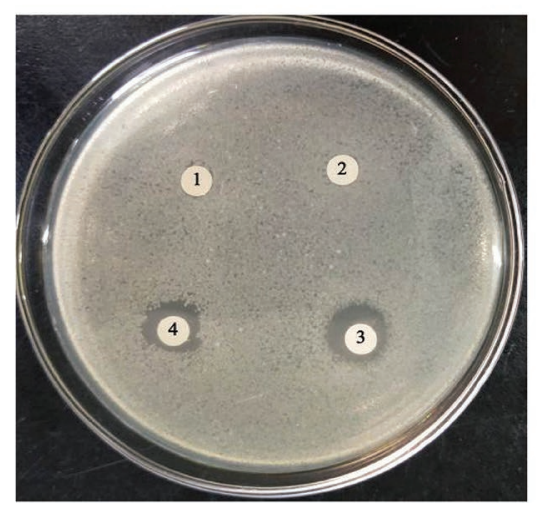

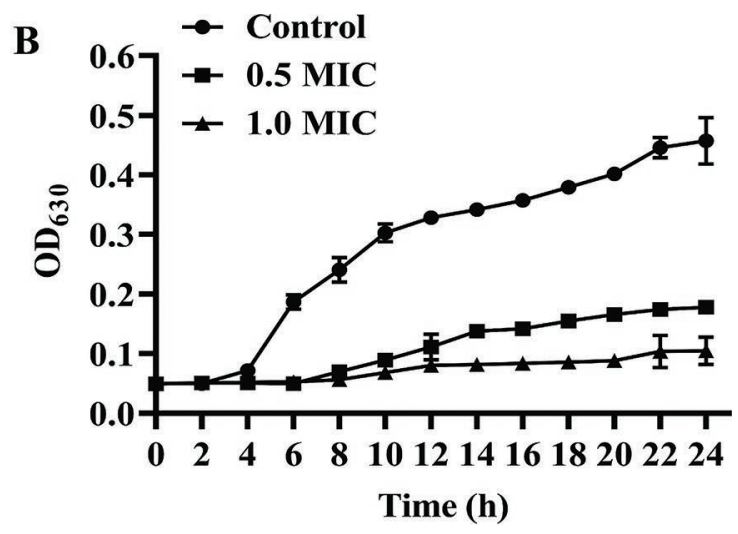

Figure 4. Antimicrobial activity of novel peptide BCp12. (A) Agar disk diffusion test. $1=$ sterile water; $2=$ casein $(20 \mathrm{mg} / \mathrm{mL}) ; 3=$ tetra-

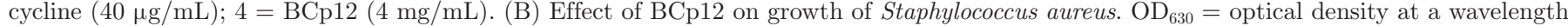
of $630 \mathrm{~nm} ; \mathrm{MIC}=$ minimum inhibitory concentration. 
it is essential to investigate the toxicity of $\mathrm{BCp} 12$. As shown in Figure 6A, its toxicity to red blood cells was examined. The hemolysis rates of $\mathrm{BCp} 12$ were 7.033, $4.572,1.854$, and $0.519 \%$, at the respective initial concentrations of 4.0, 2.0, 1.0, and $0.5 \mathrm{mg} / \mathrm{mL}$. According to previous reports, a hemolysis rate of more than $5 \%$ indicates hemolysis (Che et al., 2008). We found that BCp12 at a concentration of $4 \mathrm{mg} / \mathrm{mL}$ showed a hemolysis rate of $7.033 \%(P<0.001$ compared with negative control). Our positive control, $0.1 \%$ Triton X-100, caused complete hemolysis, whereas the negative control, PBS (pH 7.4), showed no hemolysis (Figure 6B).

Cytotoxicity of BCp12 was assessed via MTT assay in HaCaT cells (Figure 6C). In past studies, SDS has shown high cytotoxicity (Vaucher et al., 2010), revealed by cell survival rates of $0.148 \%$ at $20 \mathrm{mg} / \mathrm{mL}$ SDS. Cell survival rates in $\mathrm{BCp} 12$ were 25.211, 95.129, 98.953, and $101.371 \%$ at the respective concentrations of 1.6, $1.2,1.0$, and $0.8 \mathrm{mg} / \mathrm{mL}$. Compared with the negative control, BCp12 caused significant damage $(P<0.001)$ at high concentrations $(1.6 \mathrm{mg} / \mathrm{mL})$. As shown in Figure $6 \mathrm{D}$, HaCaT cells in the positive control $(20 \mathrm{mg} / \mathrm{mL}$ SDS) were completely ruptured, but in the $1.2 \mathrm{mg} / \mathrm{mL}$ BCp12 group, cells grew well. In the previous study, Kim et al. (2018) evaluated the toxic effects of AMP on $\mathrm{HaCaT}$ cells, which served as a prerequisite to observing the antimicrobial effect of AMP in Pseudomonas aeruginosa-infected mice in vivo. Our result could provide the basis to evaluate the efficacy of BCp12 in vivo, as with Staph. aureus-infected skin diseases.
A

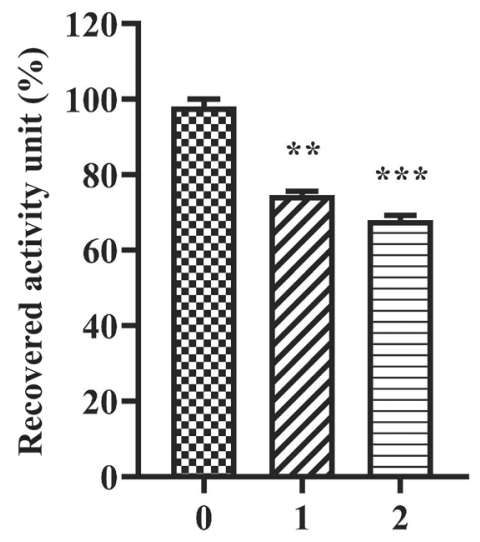

Time (h)
B

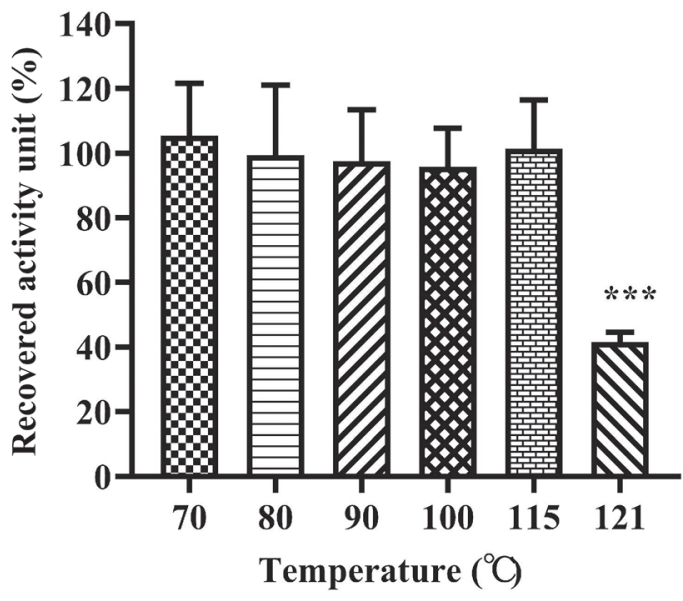

C

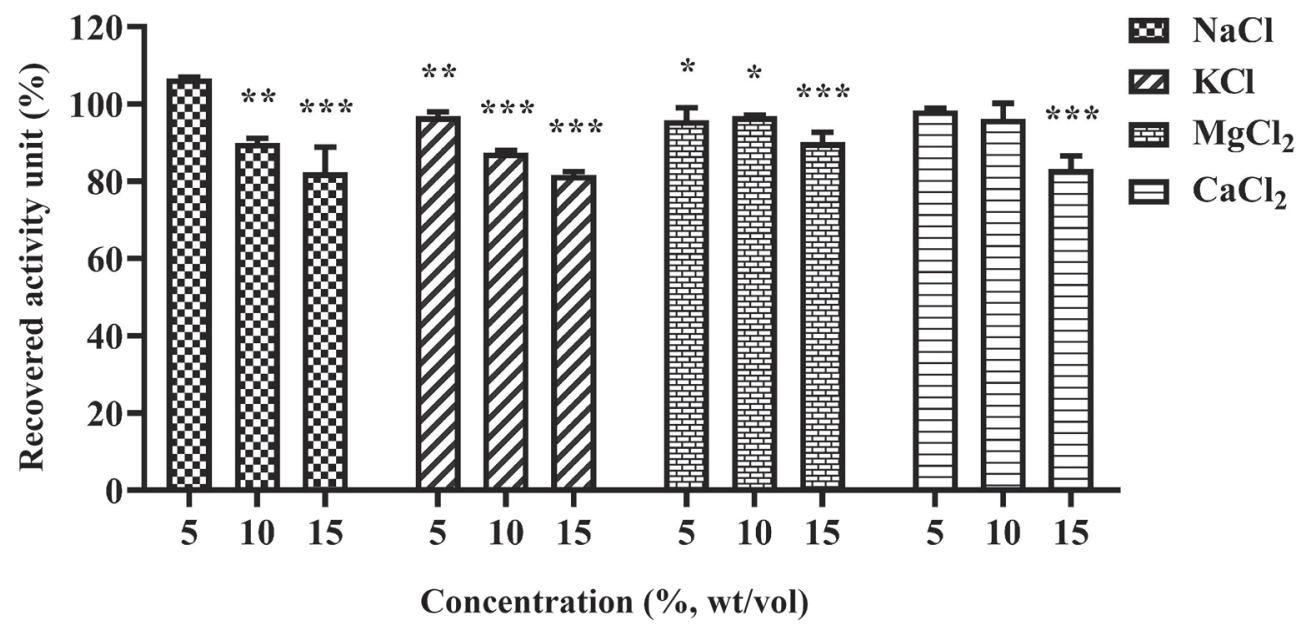

Figure 5. Recovered antimicrobial activity of novel peptide BCp12 against Staphylococcus aureus after treatment. (A) Recovered antimicrobial activity of BCp12 after incubation by trypsin. (B) Recovered antimicrobial activity of BCp12 after heating at 70, 80, 90, 100, 115, and $121^{\circ} \mathrm{C}$ for 30 min. (C) Recovered antimicrobial activity of $\mathrm{BCp} 12$ in the presence of increasing concentrations of $\mathrm{NaCl}, \mathrm{KCl}, \mathrm{MgCl}_{2}$, and $\mathrm{CaCl}_{2}$. All data presented as mean $\pm \mathrm{SD} .{ }^{*} P<0.05,{ }^{* *} P<0.01,{ }^{* * *} P<0.001$ compared with control. 


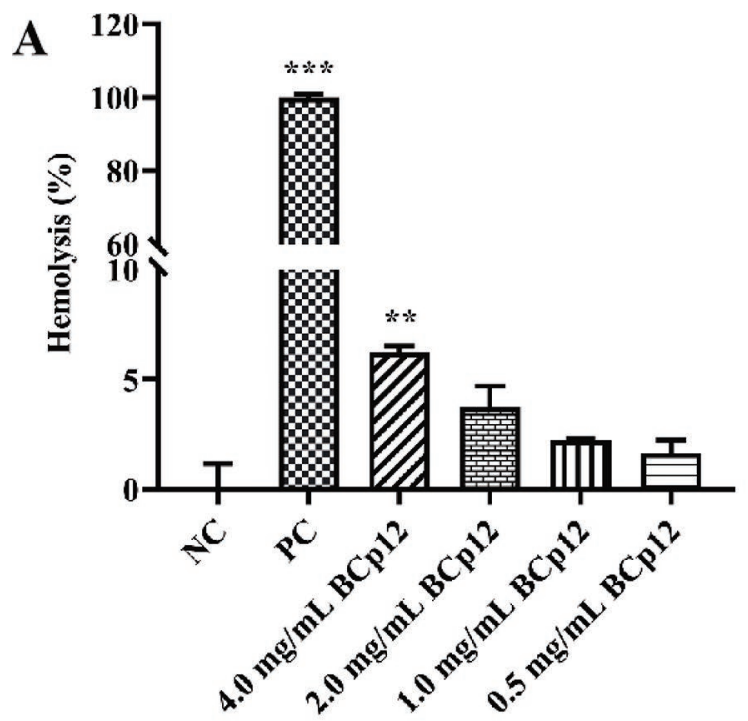

B

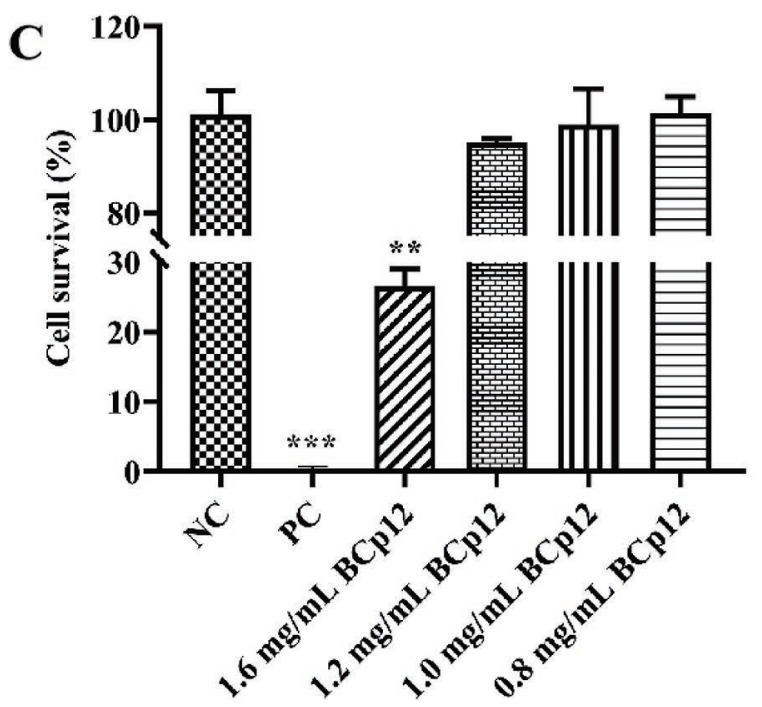

D
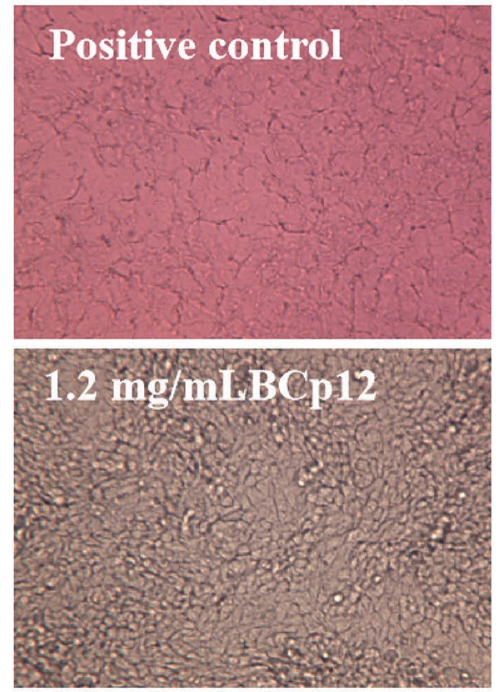

Figure 6. Hemolytic activity and cytotoxicity of novel peptide BCp12. (A) Hemolytic activity of BCp12 against red blood cells. (B) Image of hemolysis test: $\mathrm{PC}=$ positive control, $\mathrm{NC}=$ negative control, $\mathrm{BCp} 12=\mathrm{BCp} 12$ at a concentration of $4 \mathrm{mg} / \mathrm{mL}$. (C) Cytotoxicity of $\mathrm{BCp} 12$, determined by examining its effect on the survival rate of HaCaT cells using MTT [3-(4,5-dimethylthiazol-2-yl)-2,5-diphenyltetrazolium bromide] assay. (D) Experimental image of HaCaT cells. All data presented as mean $\pm \mathrm{SD}$. ${ }^{*} P<0.05,{ }^{* *} P<0.01$, ${ }^{* * *} P<0.001$ compared with control.

\section{CONCLUSIONS}

In this study, we successfully isolated a novel AMP from buffalo casein hydrolysate. The peptide derived from $\alpha_{\mathrm{S}_{1}}$-casein, named $\mathrm{BCp} 12$, exhibits amphipathic $\alpha$-helical structures, with high hydrophobic moments and net positive charge. We determined that BCp12 exhibited potent antimicrobial activity and high stability against salts and temperatures up to $121^{\circ} \mathrm{C}$. Furthermore, BCp12 induced low hemolytic and cytotoxic effects on mammalian cells at concentrations less than $4.0 \mathrm{mg} / \mathrm{mL}$ and $1.6 \mathrm{mg} / \mathrm{mL}$, respectively. Overall, BCp12 is an effective inhibitor against bacterial pathogens, with potential applications in the food and medical fields, such as use as a preservative for dairy products and as an antibiotic substitute for treating Staph. aureus-infected skin diseases.

\section{ACKNOWLEDGMENTS}

This work was financially supported by the Key Yunnan Agricultural Foundation Project (Kunming, China; Grant No. 2018FG001-011) and the National Natural Science Foundation of China (Beijing; Grant No. 31960462). We sincerely thank Sumei Li, Song Duan, Changhang Chen, and Min Yang (College of Food Sci- 
ence and Technology, Yunnan Agricultural University, Kunming, China) for their help in this study. The authors declare no conflicts of interest.

\section{REFERENCES}

Abdel-Hamid, M., H. A. Goda, C. De Gobba, H. Jenssen, and A. Osman. 2016. Antibacterial activity of papain hydrolysed camel whey and its fractions. Int. Dairy J. 61:91-98. https://doi.org/10.1016/ j.idairyj.2016.04.004.

Abdou, A. M., S. Higashiguchi, A. M. Aboueleinin, M. Kim, and H. R. Ibrahim. 2007. Antimicrobial peptides derived from hen egg lysozyme with inhibitory effect against bacillus species. Food Control 18:173-178. https://doi.org/10.1016/j.foodcont.2005.09.010.

Al Saiqali, M., A. D. Tangutur, C. Banoth, and B. Bhukya. 2018. Antimicrobial and anticancer potential of low molecular weight polypeptides extracted and characterized from leaves of Azadirachta indica. Int. J. Biol. Macromol. 114:906-921. https://doi.org/10 .1016/j.ijbiomac.2018.03.169.

Almi-Sebbane, D., I. Adt, P. Degraeve, J. Jardin, E. Bettler, R. Terreux, N. Oulahal, and A. Mati. 2018. Casesidin-like anti-bacterial peptides in peptic hydrolysate of camel milk $\beta$-casein. Int. Dairy J. 86:49-56. https://doi.org/10.1016/j.idairyj.2018.06.016.

Arruda, M. S., F. O. Silva, A. S. Egito, T. M. S. Silva, J. L. LimaFilho, A. L. F. Porto, and K. A. Moreira. 2012. New peptides obtained by hydrolysis of caseins from bovine milk by protease extracted from the latex Jacaratia corumbensis. Lebensm. Wiss. Technol. 49:73-79. https://doi.org/10.1016/j.lwt.2012.04.001.

Bellamy, F., D. Horton, J. Millet, F. Picart, S. Samreth, and J. B. Chazan. 1993. Glycosylated derivatives of benzophenone, benzhydrol and benzhydril as potential venous antithrombotic agents. J. Med. Chem. 36:898-903. https://doi.org/10.1021/jm00059a015.

Bougherra, F., A. Dilmi-Bouras, R. Balti, R. Przybylski, F. Adoui, H. Elhameur, M. Chevalier, C. Flahaut, P. Dhulster, and N. Naima. 2017. Antibacterial activity of new peptide from bovine casein hydrolyzed by a serine metalloprotease of Lactococcus lactis subsp. lactis BR16. J. Funct. Foods 32:112-122. https://doi.org/10.1016/ j.jff.2017.02.026.

Brogden, K. A. 2005. Antimicrobial peptides: Pore formers or metabolic inhibitors in bacteria? Nat. Rev. Microbiol. 3:238-250. https: //doi.org/10.1038/nrmicro1098.

Che, Q., Y. Zhou, H. Yang, J. Li, X. Xu, and R. Lai. 2008. A novel antimicrobial peptide from amphibian skin secretions of Odorrana grahami. Peptides 29:529-535. https://doi.org/10.1016/j.peptides 2008.01.004.

Ciumac, D., H. Gong, X. Hu, and J. R. Lu. 2019. Membrane targeting cationic antimicrobial peptides. J. Colloid Interface Sci. 537:163185. https://doi.org/10.1016/j.jcis.2018.10.103.

Fang, Z., L. Xu, Y. Lin, X. Cai, and S. Wang. 2019. The preservative potential of octopus scraps peptides-zinc chelate against Staphylococcus aureus: Its fabrication, antibacterial activity and action mode. Food Control 98:24-33. https://doi.org/10.1016/j.foodcont 2018.11.015.

Farhana, M. N., H. L. Tan, Y. P. Lim, and S. N. S. Maqsood-UlHaque. 2019. Isolation of antimicrobial peptide from food protein hydrolysates: An overview. Key Eng. Mater. 797:168-176. https:// doi.org/10.4028/www.scientific.net/KEM.797.168.

Florisa, R., I. Recio, B. Berkhout, and S. Visser. 2003. Antibacterial and antiviral effects of milk proteins and derivatives thereof. Curr. Pharm. Des. 9:1257-1275. https://doi.org/10.2174/ 1381612033454810

Gao, X., Y. Chen, Z. Chen, Z. Xue, Y. Jia, Q. Guo, Q. Ma, M. Zhang, and H. Chen. 2019. Identification and antimicrobial activity evaluation of three peptides from laba garlic and the related mechanism. Food Funct. 10:4486-4496. https://doi.org/10.1039/C9FO00236G.

Gobbetti, M., F. Minervini, and C. G. Rizzello. 2004. Angiotensin i-converting-enzyme-inhibitory and antimicrobial bioactive peptides. Int. J. Dairy Technol. 57:173-188. https://doi.org/10.1111/ j.1471-0307.2004.00139.x.
Han, H. M., R. Gopal, and Y. Park. 2016. Design and membranedisruption mechanism of charge-enriched amps exhibiting cell selectivity, high-salt resistance, and anti-biofilm properties. Amino Acids 48:505-522. https://doi.org/10.1007/s00726-015-2104-0.

Haque, E., R. Chand, and S. Kapila. 2008. Biofunctional properties of bioactive peptides of milk origin. Food Rev. Int. 25:28-43. https: /doi.org/10.1080/87559120802458198.

Hayes, M., R. P. Ross, G. F. Fitzgerald, C. Hill, and C. Stanton. 2006. Casein-derived antimicrobial peptides generated by Lactobacillus acidophilus dpc6026. Appl. Environ. Microbiol. 72:2260-2264. https://doi.org/10.1128/AEM.72.3.2260-2264.2006.

Ji, S., W. Li, L. Zhang, Y. Zhang, and B. Cao. 2014. Cecropin Amelittin mutant with improved proteolytic stability and enhanced antimicrobial activity against bacteria and fungi associated with gastroenteritis in vitro. Biochem. Biophys. Res. Commun. 451:650-655. https://doi.org/10.1016/j.bbrc.2014.08.044.

Kim, M. K., H. K. Kang, S. J. Ko, M. J. Hong, J. K. Bang, C. H. Seo, and Y. Park. 2018. Mechanisms driving the antibacterial and antibiofilm properties of hp1404 and its analogue peptides against multidrug-resistant pseudomonas aeruginosa. Sci. Rep. 8:1763. https://doi.org/10.1038/s41598-018-19434-7.

Kobbi, S., R. Balti, A. Bougatef, G. Le Flem, L. Firdaous, M. Bigan, G. Chataigné, S. Chaabouni, P. Dhulster, and N. Nedjar. 2015. Antibacterial activity of novel peptides isolated from protein hydrolysates of rubisco purified from green juice alfalfa. J. Funct. Foods 18:703-713. https://doi.org/10.1016/j.jff.2015.09.007.

Lombardi, L., A. Falanga, V. Del Genio, and S. Galdiero. 2019. A new hope: Self-assembling peptides with antimicrobial activity. Pharmaceutics 11:166. https://doi.org/10.3390/pharmaceutics11040166.

López-Expósito, I., J. Á. Gómez-Ruiz, L. Amigo, and I. Recio. 2006. Identification of antibacterial peptides from ovine $\alpha_{\mathrm{S}^{2}}$-casein. Int. Dairy J. 16:1072-1080. https://doi.org/10.1016/j.idairyj.2005.10 .006 .

López-Expósito, I., and I. Recio. 2008. Protective effect of milk peptides: Antibacterial and antitumor properties. Adv. Exp. Med. Biol. 606:271-294. https://doi.org/10.1007/978-0-387-74087-4_11.

Ma, Y., S. Ding, Y. Fei, G. Liu, H. Jang, and J. Fang. 2019. Antimicrobial activity of anthocyanins and catechins against foodborne pathogens Escherichia coli and Salmonella. Food Control 106:106712. https://doi.org/10.1016/j.foodcont.2019.106712.

Meisel, H. 1998. Overview on milk protein-derived peptides. Int. Dairy J. 8:363-373. https://doi.org/10.1016/S0958-6946(98)00059-4.

Meng, C., M. Wang, J. Zhang, G. Wang, X. Liu, Y. Jing, and T. Wang. 2016. Isolation and activity of antimicrobial peptide from body wall of Apostichopus japonicas. Shipin Kexue 37:33-38. https: //doi.org/10.7506/spkx1002-6630-201607007.

Mosmann, T. 1983. Rapid colorimetric assay for cellular growth and survival: Application to proliferation and cytotoxicity assays. J. Immunol. Methods 65:55-63. https://doi.org/10.1016/0022 $-1759(83) 90303-4$

Mulvihill, D. M. 1992. Production, functional properties and utilization of milprote in products. Pages 369-405 in Advanced Dairy Chemistry. Vol. 1: Proteins. P. F. Fox, ed. Springer, London, UK.

Otte, J., S. M. Shalaby, M. Zakora, A. H. Pripp, and S. A. El-Shabrawy. 2007. Angiotensin-converting enzyme inhibitory activity of milk protein hydrolysates: Effect of substrate, enzyme and time of hydrolysis. Int. Dairy J. 17:488-503. https://doi.org/10.1016/J .idairyj.2006.05.011.

Pellegrini, A. 2003. Antimicrobial peptides from food proteins. Curr. Pharm. Des. 9:1225-1238. https://doi.org/10.2174/ 1381612033454865

Peters, B. M., M. E. Shirtliff, and M. A. Jabra-Rizk. 2010. Antimicrobial peptides: Primeval molecules or future drugs? PLoS Pathog. 6:e1001067. https://doi.org/10.1371/journal.ppat.1001067.

Pichu, S., J. M. C. Ribeiro, and T. N. Mather. 2009. Purification and characterization of a novel salivary antimicrobial peptide from the tick, Ixodes scapularis. Biochem. Biophys. Res. Commun. 390:511515. https://doi.org/10.1016/j.bbrc.2009.09.127.

Porto, W. F., A. S. Pires, and O. L. Franco. 2017. Computational tools for exploring sequence databases as a resource for antimicrobial 
peptides. Biotechnol. Adv. 35:337-349. https://doi.org/10.1016/j .biotechadv.2017.02.001.

Shazly, A. B., Z. He, M. A. El-Aziz, M. Zeng, S. Zhang, F. Qin, and J. Chen. 2017. Fractionation and identification of novel antioxidant peptides from buffalo and bovine casein hydrolysates. Food Chem. 232:753-762. https://doi.org/10.1016/j.foodchem.2017.04.071.

Sibel Akalın, A. 2014. Dairy-derived antimicrobial peptides: Action mechanisms, pharmaceutical uses and production proposals. Trends Food Sci. Technol. 36:79-95. https://doi.org/10.1016/j.tifs 2014.01.002

Tang, W., H. Yuan, H. Zhang, L. Wang, H. Qian, and X. Qi. 2015. An antimicrobial peptide screened from casein hydrolyzate by Saccharomyces cerevisiae cell membrane affinity method. Food Control 50:413-422. https://doi.org/10.1016/j.foodcont.2014.09.030.

Tang, Y. L., Y. H. Shi, W. Zhao, G. Hao, and G. W. Le. 2009. Discovery of a novel antimicrobial peptide using membrane bindingbased approach. Food Control 20:149-156. https://doi.org/10 .1016/j.foodcont.2008.03.006.

Vaucher, R. A., A. de Souza da Motta, and A. Brandelli. 2010. Evaluation of the in vitro cytotoxicity of the antimicrobial peptide. Cell Biol. Int. 34:317-323. https://doi.org/10.1042/CBI20090025.

Wang, H., Y. Wang, and A. Huang. 2017. Influence of Dregea sinensis Hemsl. protease on the quality of mozzarella cheese from buffalo milk. Emir. J. Food Agric. 29:539-546. https://doi.org/10.9755/ ejfa.2016-09-1227.
Zasloff, M. 2002. Antimicrobial peptides of multicellular organisms. Nature 415:389-395. https://doi.org/10.1038/415389a.

Zhang, S. 2011. Preparation and releasing characteristics of recombinant penaeidin3-2 microcapsules Doctoral dissertation. Institute of Oceanology, Chinese Academy of Sciences, Beijing, China.

Zhang, Y., H. Wang, L. Tao, and A. X. Huang. 2015. Milk-clotting mechanism of Dregea sinensis Hemsl. protease. J. Dairy Sci. 98:8445-8453. https://doi.org/10.3168/jds.2015-9851.

Zhang, Y., Z. Ying, and S. Wang. 2012. Comparative analysis of the composition of the Betel River buffalo, Mora buffalo and Holstein milk. China Dairy Cattle 7:24-26. https://doi.org/10.3969/j.issn .1004-4264.2012.07.010.

Zhao, C., X. Wang, M. Huang, G. Wei, and A. Huang. 2018. Study on enzymatic hydrolysis of goat milk preparation casein glycomacropeptide by protease in Dregea sinensis (Hemsl.). China Dairy Industry 46:23-27. https://doi.org/https://10.3969/j.issn.1001-2230 .2018.09.005.

\section{ORCIDS}

Aixiang Huang (ํ) https://orcid.org/0000-0003-4148-8455 